\title{
Investigating Related Factors on Creating a Competitive Advantage in Health Tourism Business: A Case Study
}

\author{
Hakimeh Kiakojuri $^{1}$ (D), Mohammad Ali Nasimi ${ }^{\star *}$ (D), Mohammad Javad TaghiPourian ${ }^{3}$ (D), Qeidar \\ Ghanbarzadeh 4
}

\begin{abstract}
Introduction: Today, health tourism is one of the growing sectors of the tourism industry in the world. Health tourism as a source of income and job creation can be an approach to national economic development. Therefore, the aim of this study was to identify the factors related to creating a competitive advantage in the tourism business in the field of health.

Methods: This descriptive analytical study was conducted cross-sectionally in 2019. The Target population of this study includes activists and business owners of Mazandaran tourism industry. A questionnaire was used to collect data. Experts were used to measure the validity of the questionnaire. Two hundred copies were distributed, out of which 165 questionnaires were completed and returned. The reliability of the data collection tool was confirmed by Cronbach's alpha and composite reliability. Data analysis used structural equation method and Smart PLS software.

Results: The results showed that the socio-cultural situation with a path coefficient of 0.96 had a significant effect on creating a competitive advantage in health tourism in Mazandaran province. Having welfare access to accommodation, recreational facilities, and skilled manpower with a route coefficient of 0.95 and 0.85 were in the next ranks, respectively.

Conclusion: While identifying the exact list of socio-cultural and historical capabilities of the province and introducing the welfare complexes and service-treatment centers, the trustees of the organizations should provide the necessary preparations for attracting health tourists. Furthermore, ways to identify facilities for tourists should be facilitated. Also, by training and employing skilled labor, the health tourism business will be strengthened.
\end{abstract}

Keywords: Competitive Advantage, Health Tourism, Business, Mazandaran Province

- Received: 26/Dec/2019 • Modified: 27/Feb/2020 • Accepted: 17/March/2020

1. PhD Student in Entrepreneurship, Department of Management, Chalous Branch, Islamic Azad University, Chalous, Iran, kiakojuri.h@gmail.com

2. Assistant Professor, Department of Management, Tonekabon Branch, Islamic Azad University, Tonekabon, Iran, ali_nassimi2002@yahoo.com

3. Assistant Professor, Department of Management, Chalous Branch, Islamic Azad University, Chalous, Iran,jpouryan@gmail.com

4. Assistant Professor, Department of Management, Islamic Azad University, Chalous, Iran, gheydar_2005@yahoo.com 


\section{واكاوى عوامل مرتبط بر خلق مزيت رقابتى در كسبوكار كَردشَّى سلامت: مطالعه موردى}

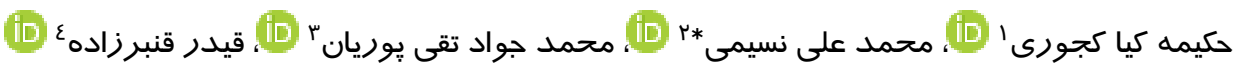

حكيده

مقدمه: امروزه كردشكرى سـلامت از رو به رشـدترين بخشهاى صنعت كردشكرى در جهان است. كردشـكرى سـلامت

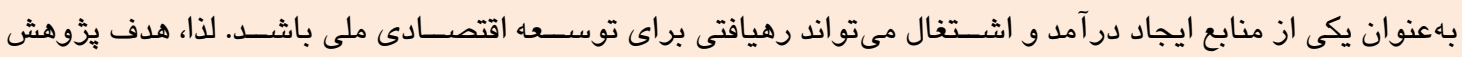
حاضر شناسايى عوامل مرتبط بر خلق مزيت رتابتى در كسبوكار كردشكرى در حوزه سلامت است

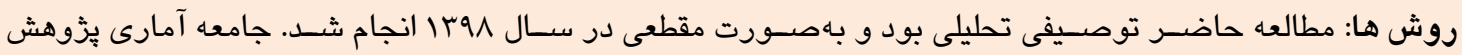

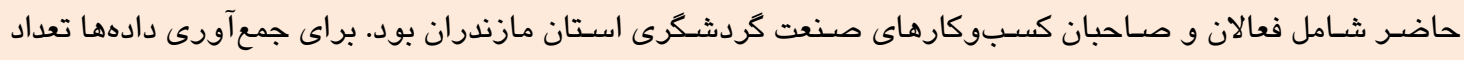

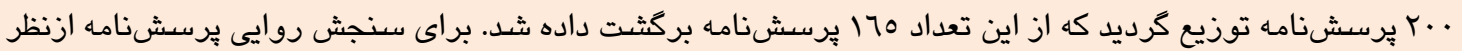

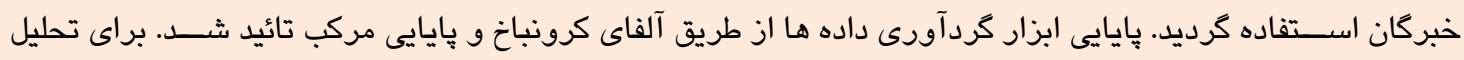

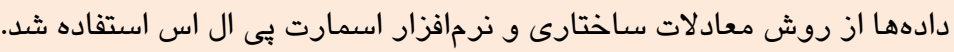

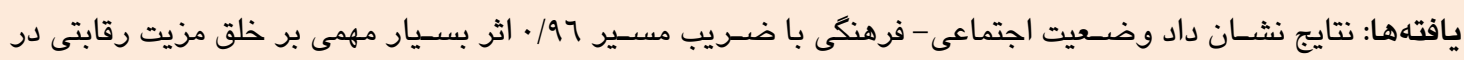

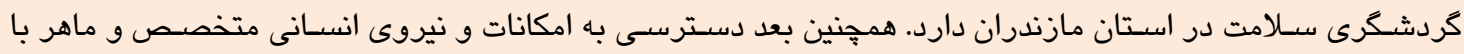

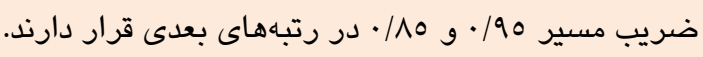
نتيجه يُرى: متوليان سـازمانهاى ضـمن مشـخص نمودن فهرست دقيق قابليتهاى اجتماعى - فرهنكى و تاريخى اسـتان و معرفى مجتمع هاى رفاهى و مراكز خدماتى - درمانى، مقدمات لازم در جذب كردشـحر سـلامت را فراهم نمايند. در ادامه

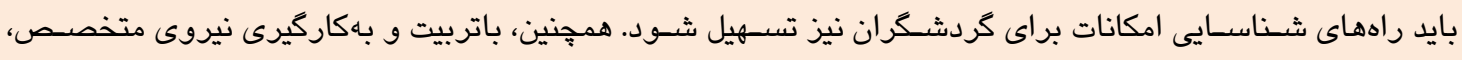
كسبوكار كردشكرى سلامت تقويت خواهد شدا. وازههاى كليدى: مزيت رقابتى، كردشكرى سلامت، كسبوكار، استان مازندران.

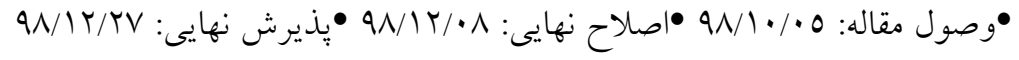

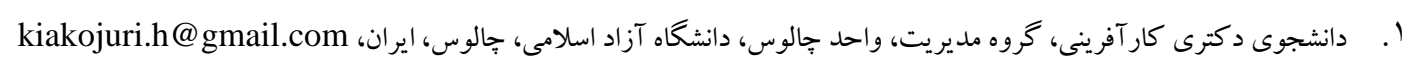

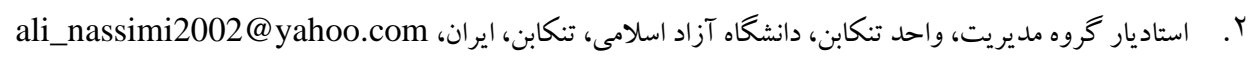

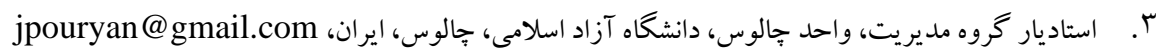

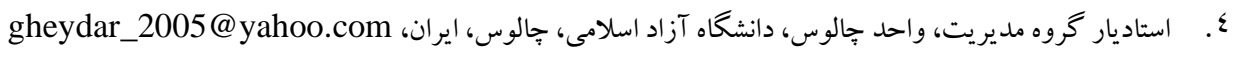


باشد.)[9]صنعت گ گرشخرى براى كشورهايى كه با

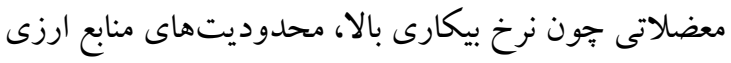

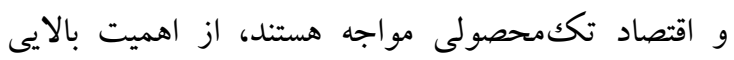

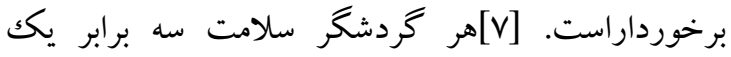

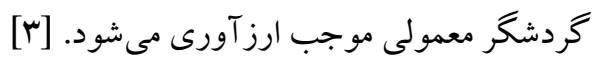

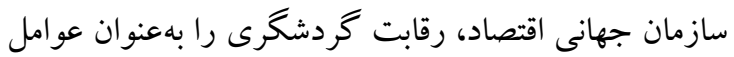

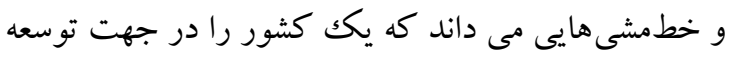

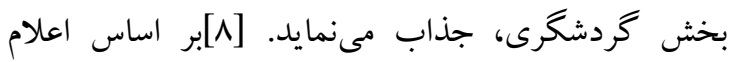
سازمان همكارى و توسعه اقتصادى، تعداد گردشگران

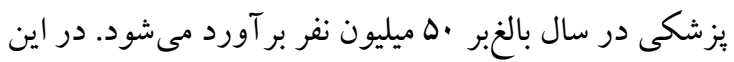

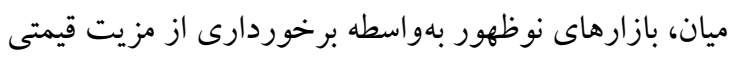

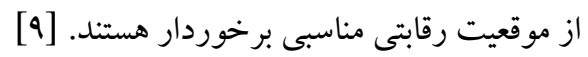
سازمان جهانى گردشخرى، گر دشخرى سلامت را را استفاده از

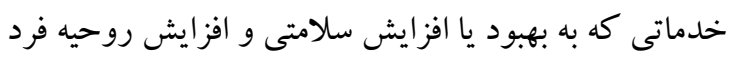
منجر مى شود و در مكانى خارج از محل سكونت فرد است و بيش از YF ساعت به طول انجامد، تعريف مى كند. توريسم سلامت شامل افراد و گروههايى است كه براى استفاده از

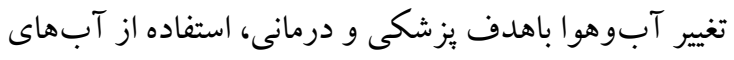

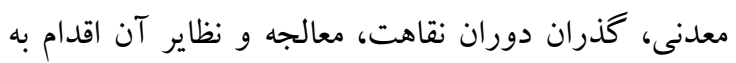

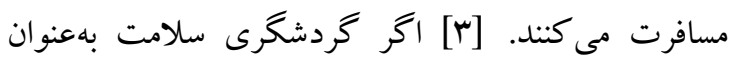
اولويت در نظر گرفته شود، علاوه بر مزاياى سلامتى براى افر اد و جامعه، مىتواند بهصورت بالقوه خارج شدن ارز و نيروى انسانى به ديخر كشورها جلو گيرى نمايد. [.1]

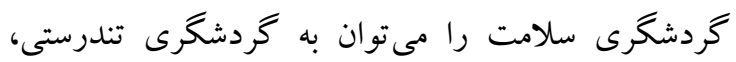

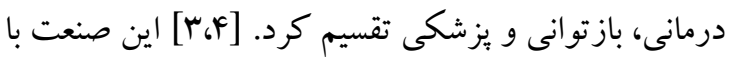

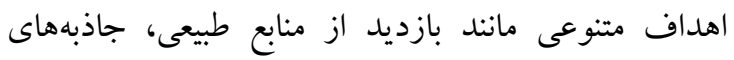
تاريخى و باستانى، به دست آوردن سلامت جسمى و روحى مانى

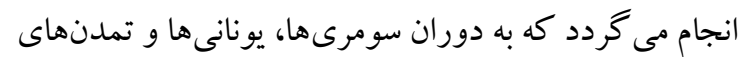

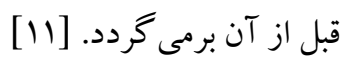
در اين ميان، تنوع، كيفيت بالاو قيمت پيايين خدمات درد درمانى

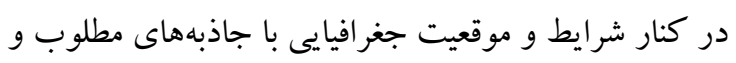
قابليت دسترسى به امكانات رفاهى، اقامتى و تفريحى، عو امل مر تبط در جذب گردشخر سلامت در كشور به شمار مى آيند.

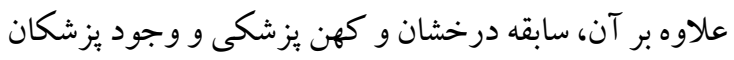

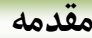

در دنياى رقابتى هر سازمانى به دنبال انجام خدماتى مؤثرتر از

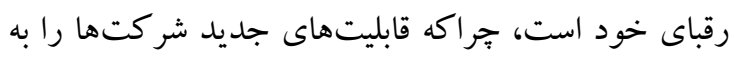
جابككتر بودن و همراستايى رقابت در بازار وادار مى سازد.

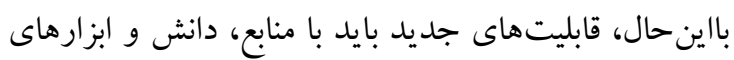

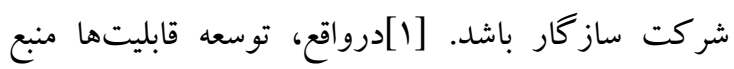
بالقوهاى براى مزيت رقابتى شر كتها است، دانش و قابليتها

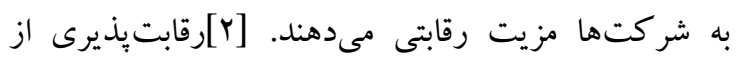

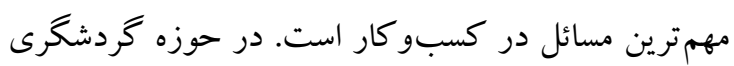

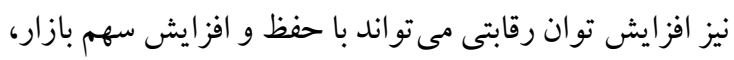

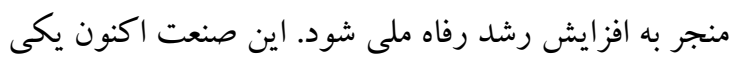

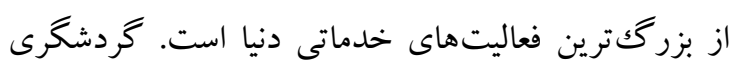

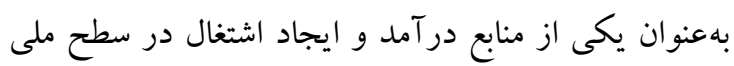

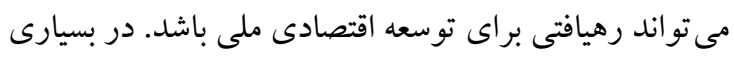

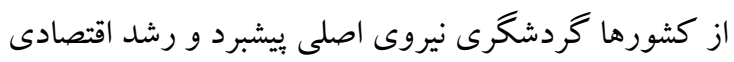
محسوب مى شود و بهقدرى در توسعه اقتصادى - اجتماعى كشورها اهميت يافته است كه اقتصاددانان آن را صادرات نامرئى نام نهادهاند. [ץ[]|ين صنعت در بسيارى از كشورها

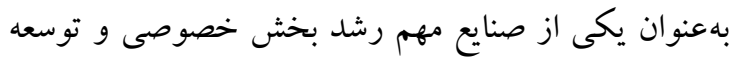

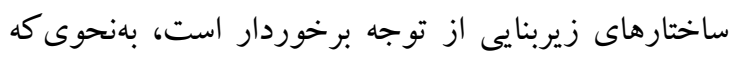

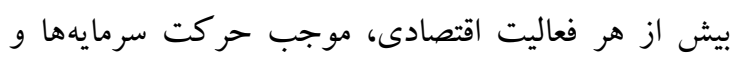

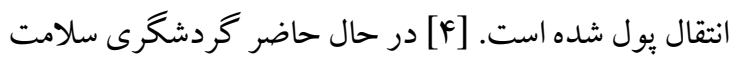
از رو به رشدترين بخشهاى صنعت گردشكرى در جهان

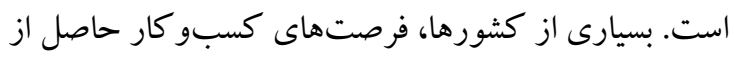
سفرهاى بزشكى را، بهخصوص از زمانى كه با با صنعت كردشخرى تر كيب شده، است به رسميت شناختهاند. [هـ

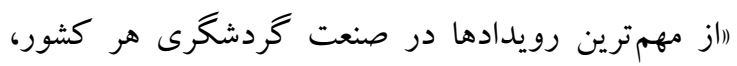
ميزان تقاضا براى يكك محصول يا مقصد كردشخرى است. البته، تمامى صنايع به جنين كاهش ريسكى علاقه مند هستند.

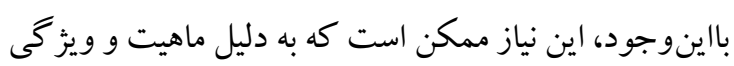
هاى صنعت و فعاليت هاى گردشخرى (غيرقابل ذخيره بودن،

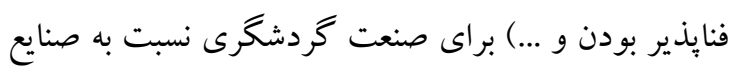
عرضه كننده ديخر محصولات و خدمات، مبرم و حادتر 
است. [19]مرورى كذرا بر هتلها، مجتمعهاى اقامتى و

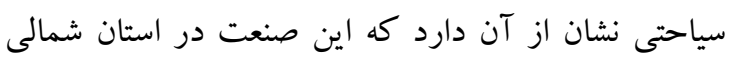

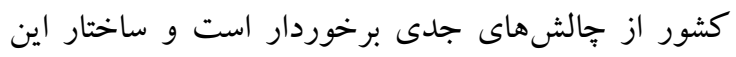
صنعت در شمال كشور بهخوبى شكل نكرفته و از يكك بافت

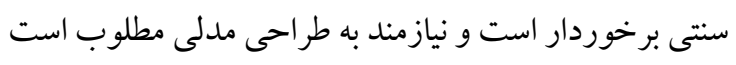

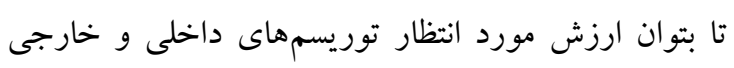

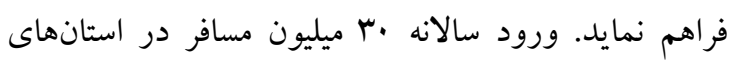
شمالى و رضايت نداشتن گردشخُران از شرايط و امكانات توريسمى در ابعاد مختلف اين صنعت، نيازمند شناسايى شاخصهاى خلق مزيت رقابتى اين صنعت است. استان

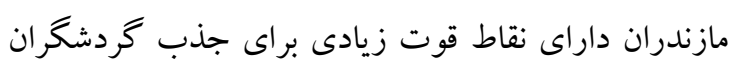

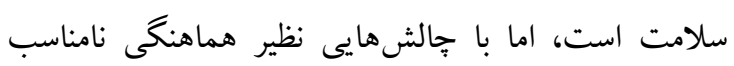

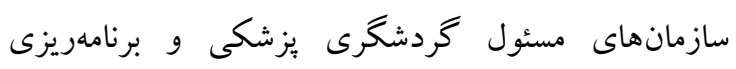

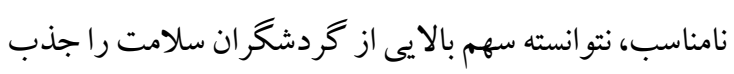

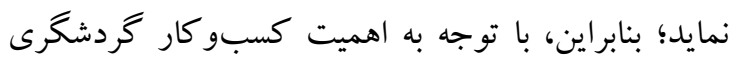

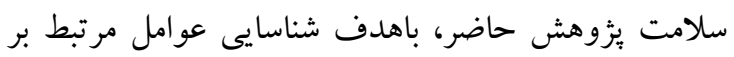
خلق مزيت رقابتى در كسبو كار گردشخرى حوزه سلامت در استان مازندران انجام شد.

\section{روشها}

يزوهش حاضر ازنظر ماهيت روش توصيفى - تحليلى و ازنظر هدف، كاربردى و بهصورت مقطعى در سال ^هبا انجام شد. بخشى از اطلاعات بهصورت كتابخانهاى و بخشى ديخر با داردي

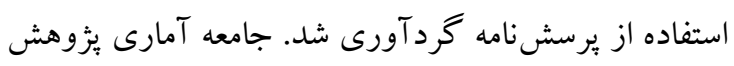
شامل سه گروه بود. كارشناسان و مديران سازمان ميراث

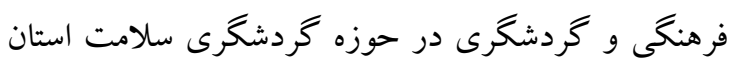
مازندران كه مطابق فهرست دريافتى از سازمان تعداد آنها

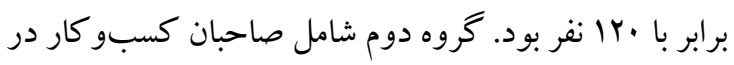

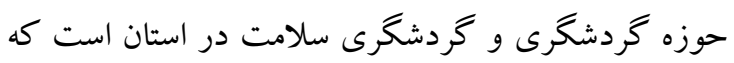

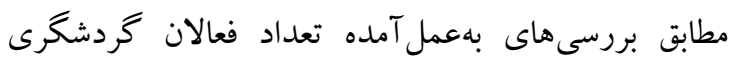

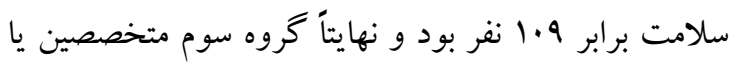

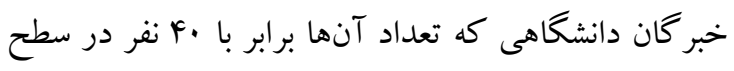
استان مازندران بود. مطابق فهرست دريافتى از سازمانهاى

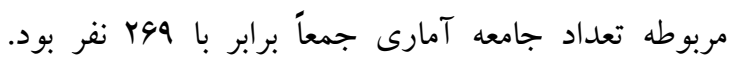

ماهر، همخى عواملى هستند كه ايران را با بتانسيلهاى بالايى

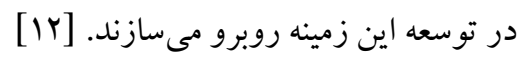

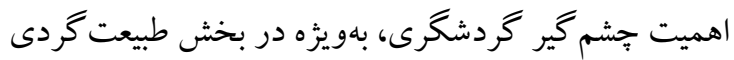
از جنبهاى مختلف در سطح جهانى بر همگًان آشكار

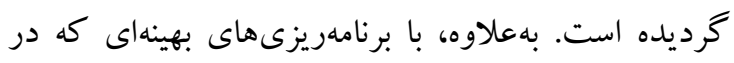

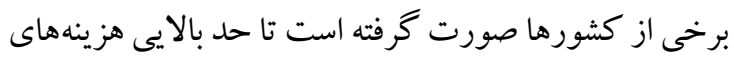
درمان كاهش يافته و همجينين زمينه بهبود و بازتوانى بيماران

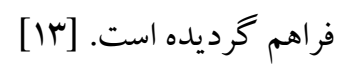

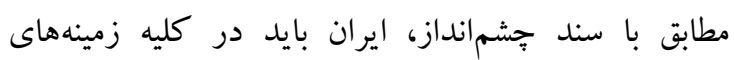
اقتصادى، اجتماعى و فرهنگى در سطح منطقه، رتبه اول را

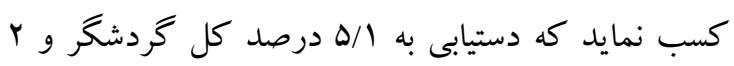

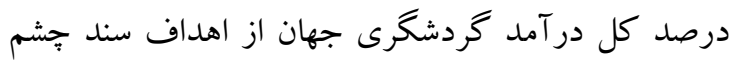

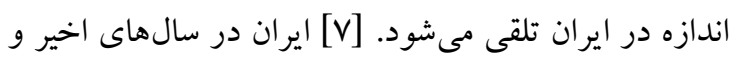

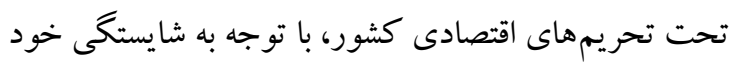
در گردشخرى يز شكى ازجمله خدمات يز شكى باكيفيت بالا و هزينه بايين بيشرفت نموده است و بايد از توانيىهاى خود

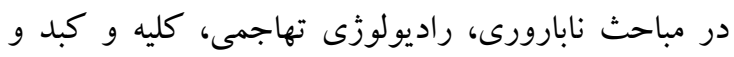
مزاياى گردشخرى يزشكى استفاده كند. ايران در توليد سلول هاى بنيادى و ترميم ضايعات نخاعى جز كشورهاى برتر

جهان است. [11] به كار گيرى ابزارهاى ايجاد ارتباط و انتقال اطلاعات براى ورود گردشخران سلامت در صنعت توريسم ضرورى است. با توجه به رقابتى شدن اين صنعت كشورها و سازمانها به دنبال استفاده از مزيتهاى رقابتى و فن آورىهاى جديد هستند تا بتواند بهخوبى زمينه را براى جذب مخاطبان هدف

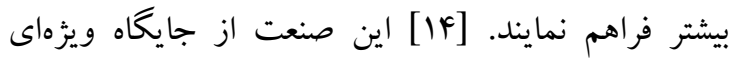
برخوردار است و با توجه به يِامدهاى مثبت اقتصادى،

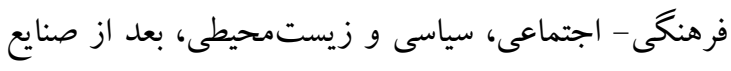
نفت و خودروسازى بهعنوان سومين صنعت بزرگك دنيا

شناخته مى إدو. [10]

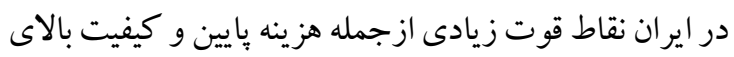
خدمات بزشكى براى جذب مشتريان سلامت است، اما با بال

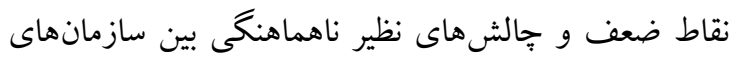
متولى گردشخرى سلامت و برنامهريزى نامناسب همراه 
تعيين مىشود و انحراف معيار عامل اصلى سنجش پيايايى است. بايايى تركيبى يكك معيار ارزيابى برازش درونى مدل

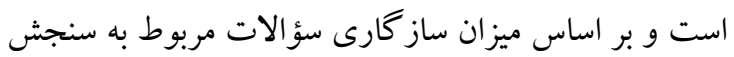

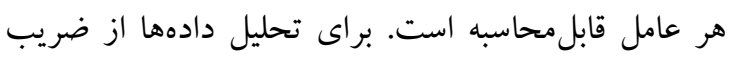
مسير استفادهد. منظور از ضرايب مسير همان بتاى استانداردشده در ركرسيون خطى است. ضرايب مسير

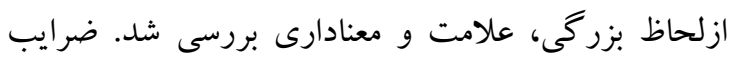

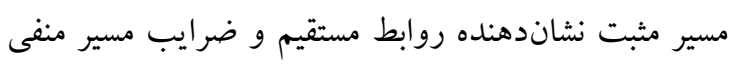

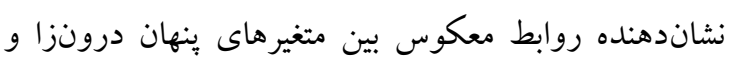

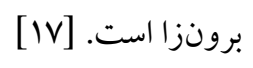

\section{يافته ها}

با توجه به مشخصات جمعيت شناختى باسخدهند كان ازلحاظ

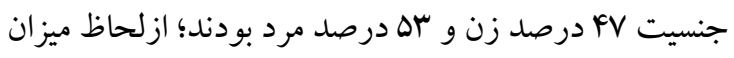
تحصيلات دو درصد دكترى، rF درصد كارشناسى ارشد، rV د درصد كارشناسى، نه درصد دييلم و نه درصد زير دييلم

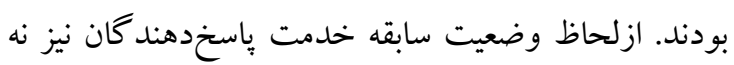

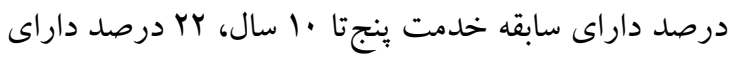
سابقه خدمت / 1 تا ها سال، •ه درصد داراى سابقه خدمت له له

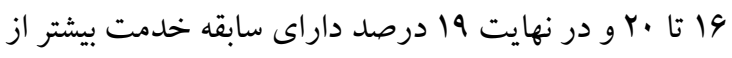

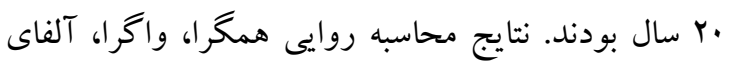

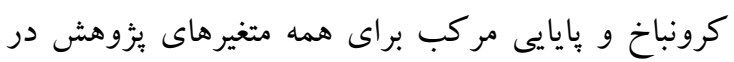
جدول دو ارائهشده است.

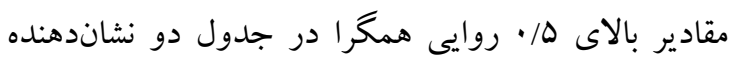
همسانى يا اعتبار دورنى مدلهاى اندازهيرى انعكاسى است.
بهمنظور تعيين حجم نمونه از جدول استاندارد كوهن و كر جسى و مور گان، استفاده شد كه حداقل حجم نمونه در هر دو روش برابر با 109 بوده است. در يزوهش حاضر، بهمنظور حصول اطمينان از دريافت كامل حداقل نمونه

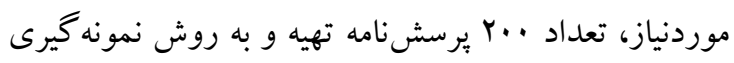

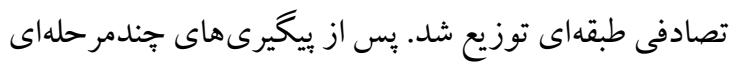

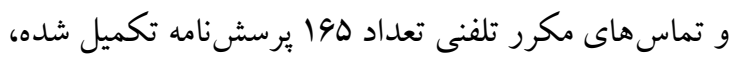
جمع آورى و تحليل شد.

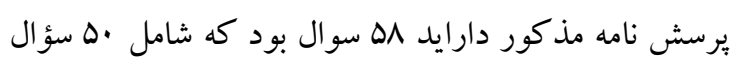

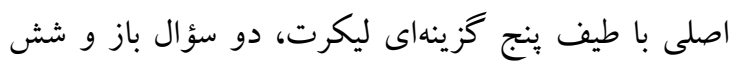

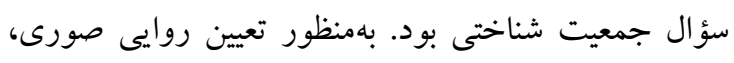

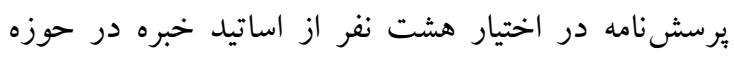
كردشخُى و مطلع به مسائل سلامت از دانشگاههاى ميراث فرهنگى و گردشخرى نوشهر (جهار نفر )، دانشخاه مازندران (سه نفر)، دانشگاه آزاد اسلامى (يكك نفر ) قرار گرفت و و تائيد شد. جدول يكك ابعاد خلق مزيت رقابتى در كسبو كار گر دشخرى سلامت را نشان مىدهد. روايى همخرا به همبستخى سؤالات يكك سازه باهم اشاره

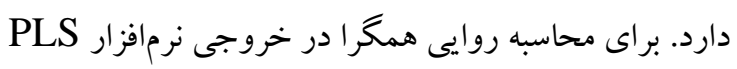

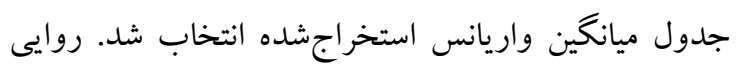
واكرا بر عدم همبستخى بين سؤالات يكك سازه با سؤالات

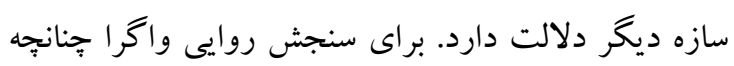

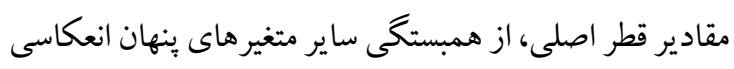

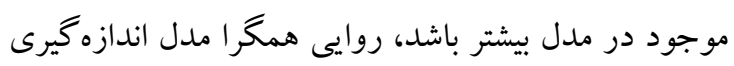

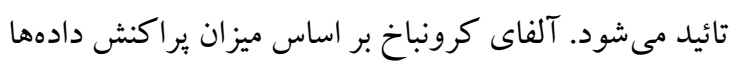

\section{جدول ا - ابعاد خلق مزيت رقابتى در كسبوكار كردشكرى سلامت}

\begin{tabular}{|c|c|}
\hline محققين & 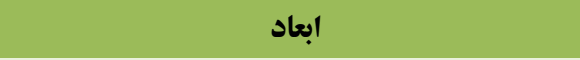 \\
\hline هرندى و همكاران [11]، محمدى و همكاران [YI]]، وانگك و همكاران [19]. & وضعيت اجتماعى و فرهنغى \\
\hline مروتى و همكاران [r]]، هان و همكاران [r·]. & مزيت رقابتى \\
\hline 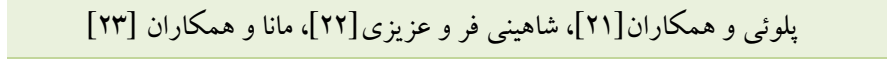 & زير ساخت هاى صنعت كردشكرى \\
\hline 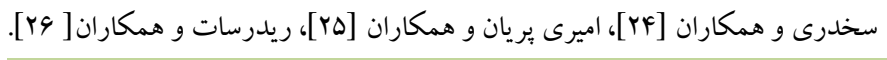 & دسترسى به امكانات رفاهى / اقامتى و تفريحى \\
\hline منوجهرى و محمدى [YrV]، دادگر و همكاران[19]]، نيلاشى و همكاران [YM]. & موقعيت زيست محيطى \\
\hline 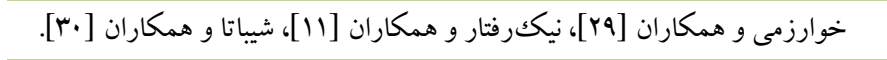 & رقابت يذيرى قيمت \\
\hline فرزين و همكاران[9]، هرندى و همكاران [1/]، آلتيناى و همكاران [1/K]. & نيروى انسانى متخصص و ماهر (مهارت يزشكان) \\
\hline
\end{tabular}


موضوعى ميانرشتهاى باشد كه هدف آن معرفى و تثبيت حوزه گردشخرى سلامت در كار آفرينى است. در اين راستا،

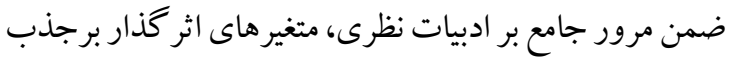
كردشكر سلامت شناسايى شده متوليان و مسئولين حوزه كردشخرى و بهويزه گردشخرى سلامت مى تو انند متغيرهاى شناسايى شده را بهعنو ان معيارهاى ارزيابى عملكرد مؤسسات گردشخرى و يا شاخصهاى ارزيابى در اعطاى مجوز قرار دهند تا با توجه به اهميت گردشخرى سلامت و شر ايط استان كسبو كارها، مطابق استانداردهاى بين المللى تأسيس و اداره شوند. يافتهاى يزؤهش نشان داد بعد وضعيت اجتماعى-

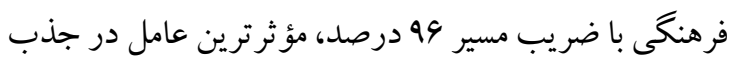
گردشگ سلامت است. مرور ادبيات نظرى يثزوهش نمايانكر اين است كه شرايط سنى و وضعيت جسمانى گردشخران مردان سلامت، داشتن نخرش مثبت گردشخر سلامت و همراهان

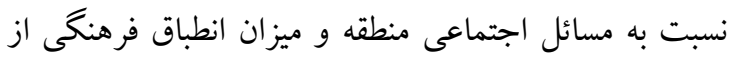
مهم ترين عوامل در انتخاب مقصد گردشخرى سلامت است. يافتهاى يزوهش نشان داد برخوردارى از آثار تاريخى و مجتمعهاى رفاهى- تفريحى و مهمانوازى به ترتيب با بانسان

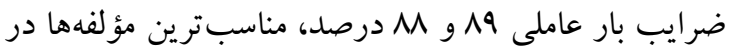
جذب گردشگر سلامت از سوى ياسخدهندگان است. همجنين، فرهنگك بومى اهالى منطقه شاخصى مناسب در

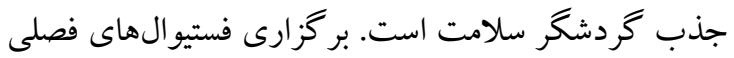
كه در بخشهاى مختلف استان برگزار مىشود، مىتواند موجبات شادى و نشاط گردشخر را فراهم آورد. يافتهاى يزوهش حاضر همراستا با نتيجه يُوهشهاى هرندى و همكاران [1/]]، محمدى و همكاران [با] ، وانگك و همكاران
درواقع شاخص ساز كارى تركيبى نسبت مجموع بارهاى

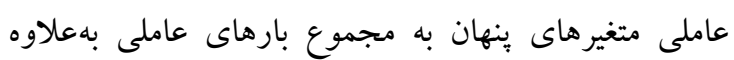

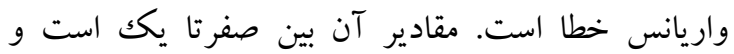
جايكزينى براى آلفاى كرونباخ است. مقدار اين شاخص بيشتر از هفت درصد است. شاخص آلفاى كرونياخ الفياخ ميزان

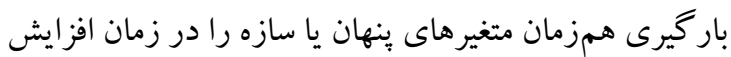

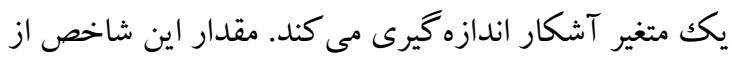

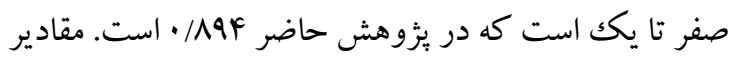
بالاى V/. در جدول دو نشاندهنده سازگارى درونى

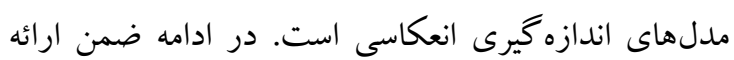

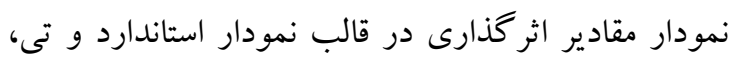
نتايج آزمون فرضيهها در قالب ضر ايب مسير و بار عاملى در در درد شكل يك ارائهده است. بار عاملى مقدار عددى است كه ميزان شدت رابطه ميان يكك متغير بنهان و متغير آشكار مربوطه راطى فر آيند تحليل مسير

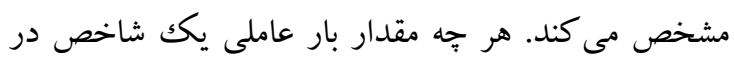

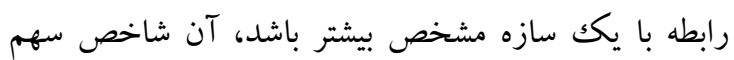
بيشترى در تبيين آن سازه ايفا مى كند. [IV] در جدول سه بار عاملى هر يكك از مؤلفهاى بثزوهش به تفكيك ارائهشده است.در ادامه نتايج آزمون فرضيههاى بُزوهش در جدول جهار ارائه شد. ضرايب مسير و آماره تى ارائهشده در جدول جهار نشان مى

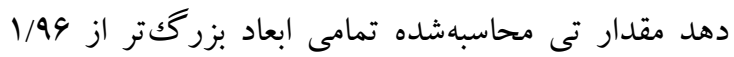
محاسبهده است، لذا مىتوان گفت اثرگذارى ابعاد شناسايى شده يزووهش معنى دار است. در اين ميان بعد وضعيت

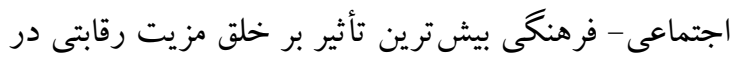

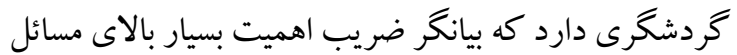
اجتماعى و فرهنگى براى ترويج گردشخرى سلامت است.

يُزوهش حاضر تلاشى در جهت كمك به شناسايى عوامل مرتبط بر خلق مزيت رقابتى در گردشگرى سلامت است تا ضمن شناسايى عوامل مرتبط و كليدى حوزه گردشخرى سلامت اولويتهاى اين صنعت را مشخص كند و و آغاز گر 
جدول r- شاخصهاى روايى و هايايى ابزار يخوهش

\begin{tabular}{|c|c|c|c|c|c|}
\hline تِ & كرونباخ & واكرا & همكرا & 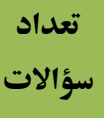 & متغيرهاى بنهان \\
\hline$\cdot /$ AYS & - / vor & $\cdot / 9 \vee \Delta$ & $\cdot / \Delta r q$ & $\wedge$ & مزيت رقابتى \\
\hline$\cdot / 9 Y 4$ & $\cdot / 9.4$ & $\cdot / 9 M M$ &.$/ 944$ & $v$ & رقابت بذيرى قيمت \\
\hline$\cdot / 949$ & - /arr &.$/ 9 P V$ &.$/ 9 Y Y$ & 9 & زيرساخت هاى صنعت كردشكرى \\
\hline$\cdot / 9 r 9$ & $\cdot / 9 \cdot 1$ & $\cdot / \wedge \cdot \cdot$ & $\cdot / 9 M$ & 9 & وضعيت اجتماعى -فرهنكى \\
\hline$\cdot / A Y F$ & $\cdot / \mathrm{VFV}$ & - /A৭4 & $\cdot / \Delta M F$ & $\wedge$ & موقعيت زيست مححيطى \\
\hline$\cdot / M 9$ & - /AFF & $\cdot /$ Arq &.$/ 91 \mathrm{~V}$ & $\Delta$ & نيروى انسانى متخصص و ماهر \\
\hline.$/ 919$ & $\cdot / / 9 \Delta$ & $\cdot / \mathrm{A} \cdot \mathrm{V}$ & $\cdot / \Delta \wedge \mid$ & $v$ & دسترسى به امكانات رفاهى / اقامتى/ \\
\hline
\end{tabular}

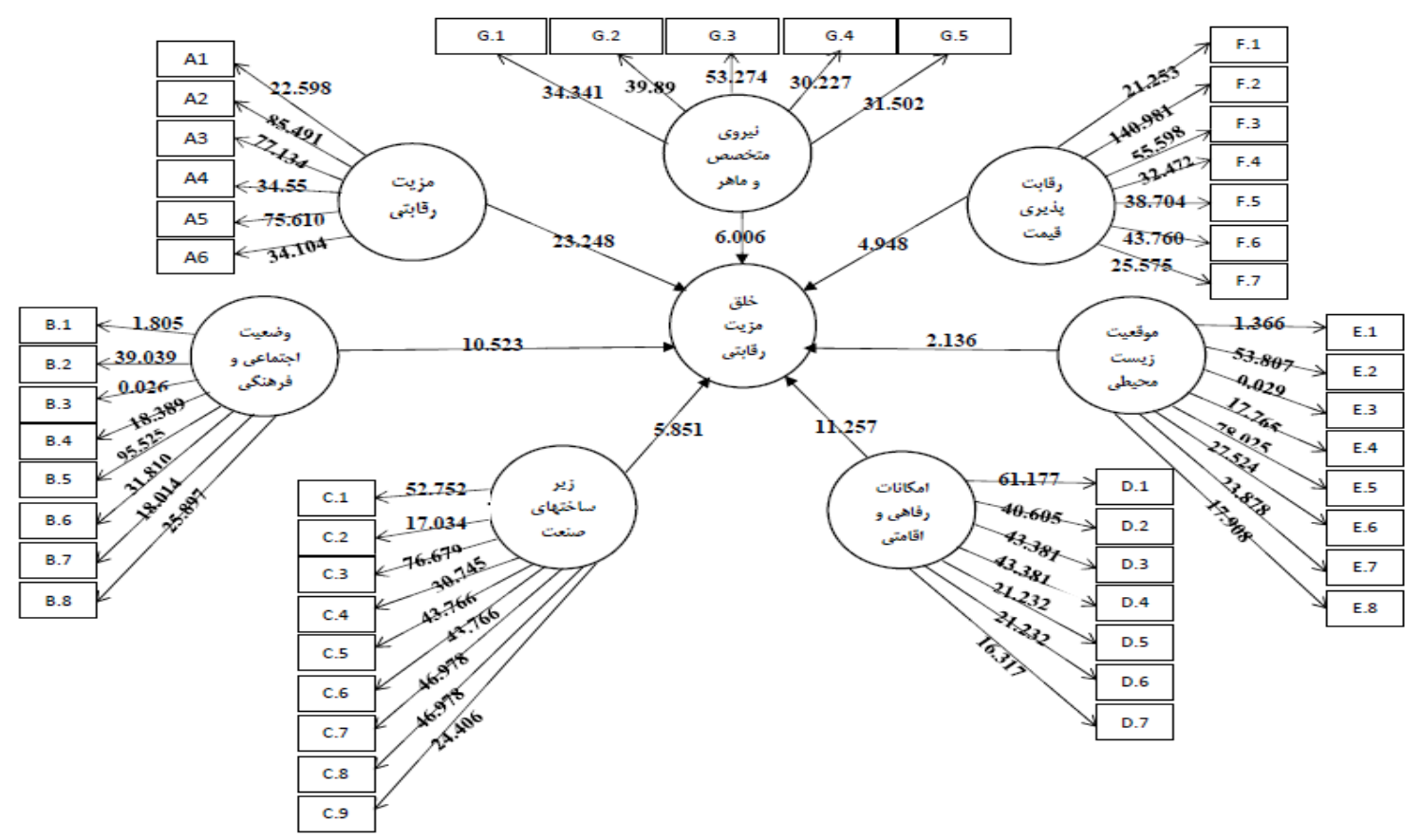

شكل 1- مدل يزٔوهش در حالت تخمين ضرايب معنادارى 
جدول بـ بار عاملى هر يك از مؤلفه هاى يخوهش

\begin{tabular}{|c|c|c|c|c|c|c|c|}
\hline دامترسى به & متيروى انسانى & زموقعيت & و وضتماعى & زيرساختهاى صرتعت & قرقابت يذيرى & رقزيت رقى & 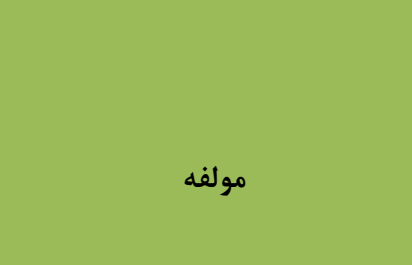 \\
\hline- & - & - & $\cdot|V Q|$ & - & - & - & فرهنَ بومى \\
\hline- & - & - & $\cdot$ / IANV & - & - & - & مهمان موازى \\
\hline- & - & - & $\cdot / \Lambda V V$ & - & - & - & ديد مطلوب \\
\hline- & - & - & $\cdot / V V G$ & - & - & - & يوش مناسب \\
\hline- & - & - & $\cdot / 199$ & - & - & - & آثار تاريخى و فرهنكى \\
\hline- & - & - & • VKr & - & - & - & تنوع و تكثر فستيوالها \\
\hline- & - & - & - & - & - & $\cdot / v \cdot \Delta$ & تجهيزات بزشكى بيشرفته \\
\hline- & - & - & - & - & - &. $\mid 948$ & شاخصهاى كيفيتى \\
\hline- & - & - & - & - & - & $\cdot / 191$ & داروخانه استاندارد \\
\hline- & - & - & - & - & - & $\cdot / v \wedge$ & مشاوره آنلاين يزشكى \\
\hline- & - & - & - & - & - & $\cdot \mid 9 \wedge \Delta$ & مراقبتهاى بهداشتى بالا \\
\hline- & - & - & - & - & - & $\cdot / N Y I$ & تهيه دارو از هلال احمر \\
\hline- & - & - & - & - & - & $\cdot / \Lambda \cdot 1$ & راحتى سفر \\
\hline- & - & - & - & - & - & $\cdot|\wedge|$ & مراكز يزشكى معتبر بينالمللى \\
\hline- & - & - & - & $\cdot|1| 1$ & - & - & منطقه امن \\
\hline- & - & - & - & - IDGT & - & - & يتانسيل هاى موجود \\
\hline- & - & - & - & $\cdot / \wedge \Delta$ & - & - & امنيت سفر \\
\hline- & - & - & - & $\cdot|1| 1$ & - & - & ايمنى در جاده \\
\hline- & - & - & - & $\cdot / \mathrm{VV}$ & - & - & راههاى مواصلاتى \\
\hline- & - & - & - & $\cdot|1| 1$ & - & - & امكانات فنى درمانى \\
\hline- & - & - & - & - IAYF & - & - & جو اجتماعى آرام \\
\hline- & - & - & - & - IArF & - & - & رضايتبخشى يروازها \\
\hline- & - & - & - & - /VAT & - & - & ايجاد راه ريلى \\
\hline$\cdot|\wedge|$ & - & - & - & - & - & - & جشمههاى آب ترم \\
\hline$\cdot / \mathrm{r}$. & - & - & - & - & - & - & مراكز درمانى زيبا \\
\hline . $/ \mathrm{A} \mid \mathrm{T}$ & - & - & - & - & - & - & جشمههاى آبمعدنى استاندارد \\
\hline$\cdot|\Lambda| r$ & - & - & - & - & - & - & خدمات تفريحى \\
\hline$\cdot 19 \cdot 9$ & - & - & - & - & - & - & صنايعدستى و بازارهاى محلى \\
\hline$\cdot / V \wedge 9$ & - & - & - & - & - & - & جشمههاى آبمعدنى ترم و سرد \\
\hline$\cdot|\Lambda|$ & - & - & - & - & - & - & روستاهاى ويزه نقاهت \\
\hline- & - & $\cdot / V V V$ & - & - & - & - & اماكن جذاب زيستى \\
\hline- & - & $\cdot / \Lambda \Delta \Delta$ & - & - & - & - & شرايط آب و هوايى \\
\hline
\end{tabular}




\begin{tabular}{|c|c|c|c|c|c|c|c|}
\hline دامترسى به & متيروى انسانى & موقعيت & و وضعيت & زير صنعت & قرقابت يذيرى & رقزيتى & 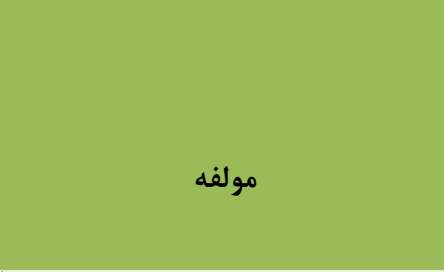 \\
\hline- & - & $\cdot / V \vee \Delta$ & - & - & - & - & طبيعت مطلوب \\
\hline- & - & - 19FT & - & - & - & - & 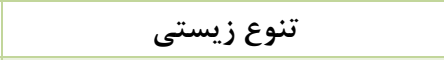 \\
\hline- & - & - /AVG & - & - & - & - & هواى مناسب براى مشكلات ريوى \\
\hline- & - & $\cdot / V \Delta \Delta$ & - & - & - & - & شرايط مطلوب دوران نقاهت \\
\hline- & - & $\cdot / V \Delta \Delta$ & - & - & - & - & جاذبه هاى گَردشگرى براى همراهان \\
\hline- & - & - lats & - & - & - & - & تعدد كَونهاى كَياهى \\
\hline- & - & - & - & - & - MAT & - & تصوير مثبت \\
\hline- & - & - & - & - & $\cdot / V \Delta S$ & - & هزينه مناسب بليط \\
\hline- & - & - & - & - & $\cdot / \vee 99$ & - & هزينه درمانى مناسب \\
\hline- & - & - & - & - & -IATV & - & تعدد اماكن يزشكى \\
\hline- & - & - & - & - & $\cdot / \mathrm{V} \Delta \Lambda$ & - & مقرونبهصرفه بودن هزينه \\
\hline- & - & - & - & - & $\cdot / V T \cdot$ & - & مراكز خريد نزديك مراكز درمانى \\
\hline- & - & - & - & - & $\cdot / 199$ & - & يايين بودن هزينه درمان يزشكى \\
\hline- & $\cdot$ /VVT & - & - & - & - & - & تخصص يزشكان \\
\hline- & - /AFr & - & - & - & - & - & 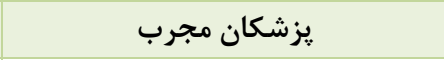 \\
\hline- & $\cdot / V \Delta \Lambda$ & - & - & - & - & - & بيمارستان ها و يزشكان معتبر \\
\hline- & $\cdot$ /VAT & - & - & - & - & - & وجود مراكز درمانى مناسب يزشكى \\
\hline- & $\cdot / \vee 91$ & - & - & - & - & - & ارتباط با تيم يزشكان و مراكز درمانى \\
\hline
\end{tabular}

جدول ع- ضرايب مسير، آماره تى، سطح معنادارى و نتيجه آزمون فرضيه هاى ثخوهش

\begin{tabular}{|c|c|c|c|c|}
\hline نتيجه & معنادارى سطح & تى آماره & ضأثريب & فرضيه \\
\hline 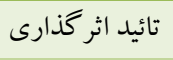 & $\mathrm{P}<\cdot / \cdot \Delta$ & $1 \cdot / \Delta r r$ & $\cdot / 90$ & مزيت رقابتى - خلق مزيت رقابتى در كردشكرى سلامت \\
\hline 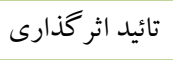 & $\mathrm{P}<\cdot / \cdot \Delta$ & $F / q F q$ & $\cdot /$ V94 & رقابت پذيرى قيمت - خلق مزيت رقابتى در كردشكرى سلامت \\
\hline 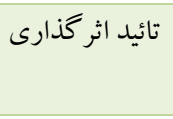 & $\mathrm{P}<\cdot / \cdot \Delta$ & $\Delta / \wedge \Delta \mid$ & $\cdot 19 \cdot 9$ & زيرساختهاى صنعت كردشكرى - خلق مزيت رقابتى در زردشكرى \\
\hline 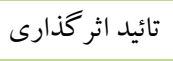 & $\mathrm{P}<\cdot / \cdot \Delta$ & TH/YYA & $\cdot / 994$ & وضعيت اجتماعى -فرهنغى - خلق مزيت رقابتى در كردشكرى سلامت \\
\hline 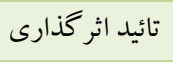 & $\mathrm{P}<\cdot / \cdot \Delta$ & r/Irs & $\cdot 19 \mathrm{~V}$ & موقعيت زيستمحيطى - خلق مزيت رقابتى در كردشكرى سلامت \\
\hline 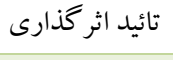 & $\mathrm{P}<\cdot / \cdot \Delta$ & $9 / . .9$ & $\cdot / \mathrm{A \Delta T}$ & نيروى انسانى متخصص و ماهر - خلق مزيت رقابتى در كردشكرى سلامت \\
\hline 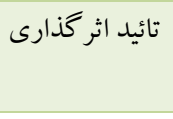 & $\mathrm{P}<\cdot / \cdot \Delta$ & $11 / Y \Delta V$ & $\cdot / 9 \Delta 1$ & درسترسى به امكانات رفاهى /اقامتى /تفريحى - خلق مزيت سلامت رقابتى در \\
\hline
\end{tabular}


مى شو مدير ان بر ايجاد و بهبو د زيرساخت هاى درمانى تأكيد داشته باشند. راهكارهاى دسترسى آسان به مر اكز درمانى ارائه شود. همجنين، ايجاد راههاى مواصلاتى مطمئن براى گردشخران، بهروز نمودن فن آورى و خدمات بيمارستانى و كيفيت خدمات و امكانات رفاهى بايد در اولويت قرار گيرد. در يثزوهش حاضر صرفاً از ديد گاه فعالان، خبر كان و متوليان استان مازندران در شناسايى عوامل مرتبط استفاده شد. درصورتى كه بهمنظور جذب گردشخر خارجى بايد ديد

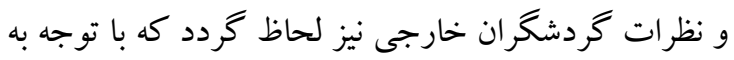

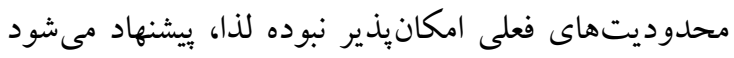

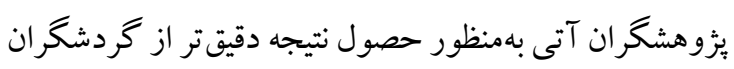
خارجى نيز در ارزيابى شاخصها استفاده كنند. در ادامه

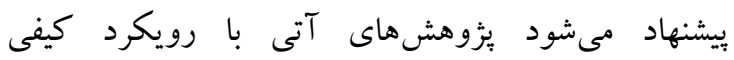
يديدارشناسانه، ابعاد و مؤلفهها بر اساس تجربه زيسته فعالان اين حوزه، شناسايى و براى ارزيابى و روايى سنجى در اختيار ساير فعالان سازمانى، شر كتى و دانشگاهى قرار گيرد.

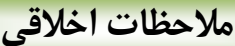

رعايت دستورالعملهاى اخلاقى: در مطالعه حاضر بهتمامى ملاحظات اخلاقى ازجمله شرط امانت و صداقت

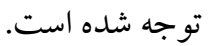
حمايت مالى: يزوهش حاضر از سوى هيج سازمانى

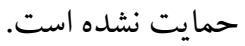
تضاد منافع: نويسند گان اظهار داشتند كه تضاد منافعى

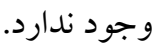
تشكر و قدردانى: اين مقاله حاصل بخشى از رساله با عنوان "اواكاوى عوامل مرتبط بر خلق مزيت رقابتى در كسبو كار

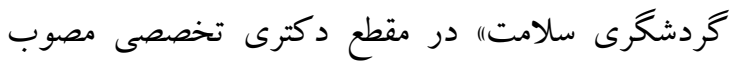

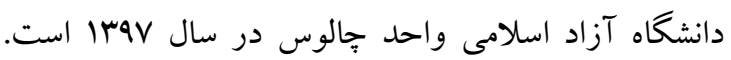

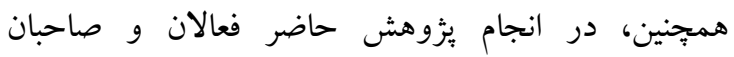

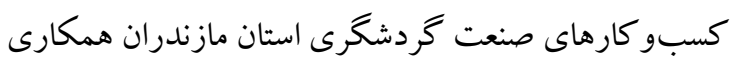
داشتهاند كه از زحمات اين عزيزان تشكر و قدردانى مىشود.
بعد مزيت رقابتى يك از عوامل اثر كذار در جذب گردشكر سلامت شناسايى شد. وجود داروخانههاى استاندارد و وجود مر اكز يز شكى معتبر بين المللى مى تواند در جذب كردشخران

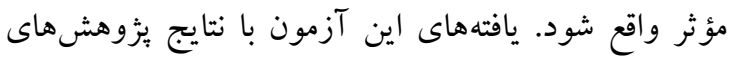
مروتى و همكاران [r] و هان و همكاران [•r] مطابقت دارد.

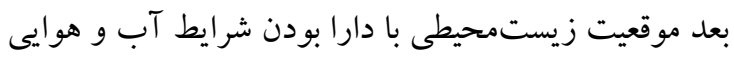
مناسب و شرايط مطلوب دوران نقاهت براى بيماران و

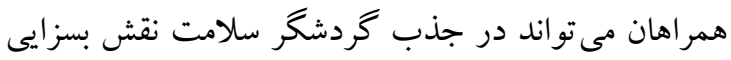

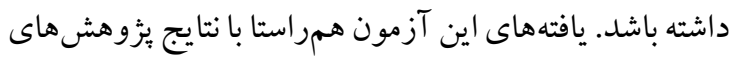

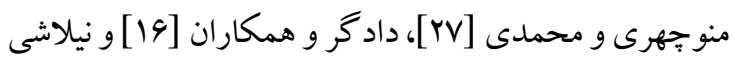
و همكاران [Yی] است.

بيشنهاد مىشود مديران محترم سازمانهاى متولى ضمن

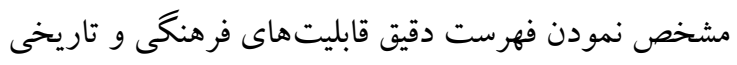
استان و معرفى مجتمع هاى رفاهى و مراكز خدماتى - درمانى

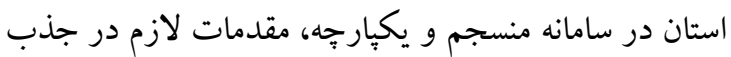

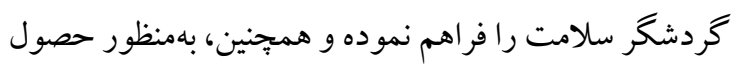

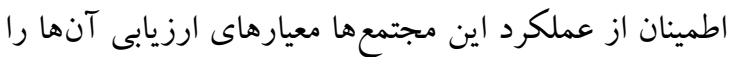

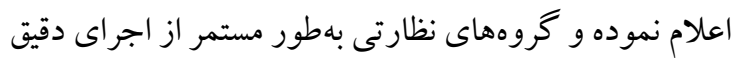
شاخص ها اطمينان حاصل نمايند. توصيه مىشود فستيو الهاى

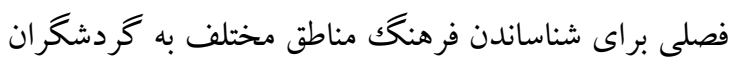
كه بهصورت منظم در استانهاى مختلف بركزار شود تا

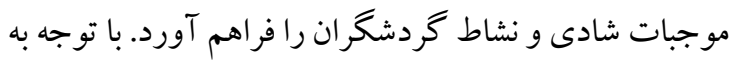
عدم اطلاع بسيارى از يزشكان و بيماران از قابليتهاى درمانى

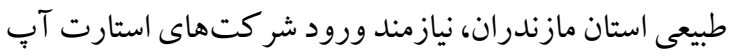
و دانشبنيان جهت معرفى دقيق اين مناطق، يّانسيلهاى طبيعى استان، خاصيتهاى دارويى و درمان اين مراكز، بسترهاى لازم در جذب گردشخر سلامت را فراهم آورد و اقدامات لازم جهت طراحى تورهاى گردشخر سلام درد بهورت سفرهاى كو تاه و بلندمدت انجام شود. مديران صنعت گردشخرى بايد در مورد تربيت نيروهاى درمانى متخصص در حوزه سلامت سرمايه گذارى نمايند تا بازدهى فرآيندهاى گردشخرى تكميل گرددد. يسيشهاد 
1. Fong H I V. Wong I K A. Hong F L J. Developing institutional logics in the tourism industry through coopetition. Tourism Management. 2018; 66: 244-262.

2. Algieri B. Aquino A. Succurro M. Competitive advantages in tourism: an eclectic view. Tourism Management Perspectives. 2018; 25: 41-52.

3 .Morovati Sharifabadi A. Asadian Ardakani F. A model for health tourism development using fuzzy topsis and interpretive structural modeling in Yazd province. Health Management Journal. 2014; 17 (55):73-88. [In Persian]

4. Babanjad I. Ashraf al-ebalad tourism opportunities are global, report of Mazandaran cultural heritage and tourism organization. 2013. [In Persian]

5. Lunt N. Smith R. Exworthy M. Green S. Horsfall D. Mannion R. Medical tourism: treatments, markets and health system implications: a scoping review. OECD. 2011; 1-55.

6 .Farzin M. Afsar A. Dabir A. Zandi E. Hybrid modeling for forecasting domestic medical tourism demand in Tehran. Journal of Health Administration. 2019; 21 (74): 51-64. [In Persian]

7 .Agharkakli A. Yahyazadefar M. Gandomfeshan, D. Esmaeili Khanbebeyn N. Study of factors affecting demand for domestic tourism in Golestan province. Tourism Planning and Development. 2019; 8(30), 177-196. [In Persian]

8. Bagheri M. Shojaei P. Kiani M. Explanation an interpretive structural model of travel and tourism competitiveness indicators (case study: Fars province). Tourism Planning and Development. 2016; 18: 137-157. [In Persian]

9. Hamidi Zadeh M R. Javidi H. Mojarrad F. Iran's competitive advantage in medical tourism marketing: a case study on open heart and cataract removal surgeries. Health Information Management. 2016; 13(5): 373-379. [In Persian]

10. Izadi M. Ayoobian A. Nasiri T. Joneidi N. Fazel M. Hosseinpour Fard M J. Health tourism in Iran opportunity or threat. Journal of Military Medicine. 2012; 14(2): 69-75. [In Persian]

11. Nikraftar T. Hosseini E. Moghadam A. Identify factors affecting medical tourism attraction in Iran. J H A. 2017; 20(67): 64-74. [In Persian]

12. Mohammadi S. Khaledi F. Analysis of affecting factors the health and satisfaction of foreign tourists (case study: Iraqi Kurdistan's tourists). Journal of Urban Tourism. 2019; 6(3): 1-16. [In Persian]

13. Rashidi M. Ramashat M. Safe A. Khoshhal Dastjerdi J. Health tourism in Iran (emphasizing on ranking of therapeutic properties of selected springs in Ardabil province). J. Health. 2012; 3(1): 49-57. [In Persian]

14. Mohammad Alipour R. Haji Amini M. Electronic marketing in the tourism industry from concepts to applications. Tehran:Cultural Research Bureau publications. 2012. [In Persian] 
15. Ghazanfarpour H. Paidar A. Sharafi H. The geography of tourism with emphasis of pilgrimage tourism.Tehrn: Noore Elm Publications. 2013. [In Persian]

16. Dadgar Y. Emamgholipour S. Hosseini S M. Health tourism efficiency in Iran and selected countries and strategies for improving the situation in Iran. Journal of Economic Studies and Policy. 2017; 14 (2): 4. [In Persian]

17. Mohsenin S. Esfidani M R. Structural equations based on the partial least squares approach. Mehraban Book Publishing Institute. Second Edition .2017. [In Persian]

18 .Harandi A .Mirzaeian Khamseh P. Explaining health tourism attraction model: using classic grounded theory strategy. Urban Tourism. 2017; 4(1): 87-98. [In Persian]

19. Wang K. XU H. Huang L. Wellness tourism and spatial stigma: a case study of Bama, China. Tourism Management. 2020; 78: 1-12.

20. Han J S. Lee T J. Ryu K. The promotion of health tourism products for domestic tourists. International Journal of Tourism Research. 2018; 20(2): 137-146.

21. Poloie K. Fazli S. Darvish F. Baiat R. Ghaderi E. Prioritizing factors affecting the development of health tourism industry in Iran in the 1414 horizons with the approach of interpretive structural modeling. Journal of Tourism and Development. 2019; 8(3): 1-29. [In Persian]

22. Shahinifar M. Azizi N. The role of health tourism in economic-social development in the City of Kermanshah (emphasizing medical tourism). Tourism Culture. 2017; 5(9): 87-95. [In Persian]

23. Manna R. Cavallone M. Ciasullo M V. Palumbo R. Beyond the rhetoric of health tourism: shedding light on the reality of health tourism in Italy. Current Issues in Tourism. 2019; 1-15.

24. Sokhdari K. Seyd Amiri N. Rajaeian A. Sokhdari J. Identification of institutional factors affecting the exploitation of entrepreneurial health tourism opportunities in Iran studied: Tehran province. Journal of Social Tourism Studies. 2019; 7 (1): 81-100. [In Persian]

25. Amiri Parian S. Yari E. Amiri Parian Z. Health and medical tourism with emphasis on knowledge of resources and potentials of Kermanshah province. Geography and Human Relationships. 2018; 1(1): 625-642. [In Persian]

26. Ridderstaat J. Singh D. De Micco F. The impact of major tourist markets on health tourism spending in the United States. Journal of destination marketing \& management. 2019; 11: 270-280.

27. Manoochehri S. Mohammadi S. Identifying and analyzing affective factors on health tourism development in Kurdistan province with emphasis on Iraqi Kurdistan regional health tourists. Border Science and Techniques. 2019; 8(3): 95-130. [In Persian]

28. Nilashi M. Samad S. Manaf A A. Ahmadi H. Rashid T A. Munshi A. et al. Factors influencing medical tourism adoption in Malaysia: a dematel-fuzzy topsis approach. Computers \& Industrial Engineering. 2019; 137. 
حكيمه كيا كجورى و همكاران

29. Kharazmi A. Rahnama M. Javan J. Shokouhi M. Factors affecting the promotion of health tourism; comparative view of foreign tourists and domestic managers. JNKUMS. 2017; 8 (3): 405-416. [In Persian]

30. Shibata N. Shinoda H. Nanba H. Ishino A. Takezawa T. Classification and visualization of travel blog entries based on types of tourism. In Information and Communication Technologies in Tourism. 2020; 27-37.

31. Altinay F. Dagli G. Altinay M. The role of technology in tourism and health services for accessibility in service management. Postmodern Openings. 2019; 10(4): 1-7. 